\title{
The Contribution of the Human Development Index Literacy Theory to the Debate on Literacy and Development
}

\author{
Idowu Biao ${ }^{1, *}$, Kebadire Mogotsi ${ }^{2}$, Tonic Maruatona ${ }^{1}$, Wapula Raditloaneng ${ }^{1}$, Flora Tladi $^{1}$, Morgan Chawawa $^{3} \&$ \\ Obakeng Kheru ${ }^{1}$ \\ ${ }^{1}$ Department of Adult Education, University of Botswana, Gaborone, Botswana \\ ${ }^{2}$ Botswana College of Agriculture, Gaborone, Botswana \\ ${ }^{3}$ Department of Research \& Community Engagement, Botho University, Gaborone, Botswana \\ *Corresponding author: Department of Adult Education, University of Botswana, Gaborone, Botswana. Tel: \\ 267-7435-9491. E-mail: idowubiaou@yahoo.com
}

Received: March 17, 2014

Accepted: April 18, 2014

Online Published: May 7, 2014

doi:10.5430/wje.v4n3p1

URL: http://dx.doi.org/10.5430/wje.v4n3p1

\begin{abstract}
The Human Development Index Literacy (HDIL) theory was developed in 2011 to eliminate or minimise the negative impact of issues underlying the failure of previous literacy programmes in promoting socio-economic development. This theory was tested for the first time between July 2013 and February 2014 in two rural communities of Botswana. A seven-item self-report inventory was developed for the purpose of recording the perceptions of 80 participants in regards to development issues, before and after training on a special literacy programme known as the Human Development Index Literacy; student's t-test was employed in testing the significance of difference between pre and post HDIL treatment scores in both communities. The findings threw up unexpected pieces of information relating to rural populace perceptions concerning the concept of development as regard justification for retaining cultural practices, craving for capital formation and other issues. The findings equally revealed that the Human Development Index Literacy theory has the potential to promote socio-economic development using the instrumentality of literacy. This is because the differences between post-HDIL treatment scores were found to be significantly higher than pre-HDIL treatment scores in both communities $(\mathrm{p} \leq .05)$ and participants actively sought ways of improving their own standard of living. This paper consequently recommends that governments of developing countries should encourage the development and commercialisation of indigenous knowledges and the adoption of the Human Development Index Literacy theory for purposes of development work.
\end{abstract}

Keywords: literacy; theory of development; developing countries; participatory development; rural communities

\section{Introduction}

For millennia, literacy skill has been used as an instrument for interpersonal communication before it began gradually and steadily to be turned into a tool for the promotion of social and economic development. Literacy began to be used as tool for socio-economic development with the birth of UNESCO in 1946 (UNESCO, 2010). For example, the major and most impactful literacy for development projects in the world to date remain the UNESCO Experimental World Literacy Programmes (Maheu, 1964 in UNESCO, 2010). However, the checkered story of the successes and failures registered in the efforts aimed at using literacy as instrument of development leaves the literacy world divided over the appropriate conclusion to draw as to the possibility of employing literacy education as a strategy for bringing about socio-economic development.

During the course of the $20^{\text {th }}$ century, a number of obstacles (poor planning, lack of political commitment, inadequate supply of human and material resources, etc.) to success in the practice area of literacy-for-development have been identified (Hautecoeur, 1997, Omolewa, 1988). Beyond the $20^{\text {th }}$ century, efforts have continued with the view to eliminating these obstacles and proffering viable solutions. One literacy theory that resulted from these efforts within the first decade of the $21^{\text {st }}$ century, was Biao's (2011) Human Development Index Literacy (HDIL) theory. The main purpose for developing the HDIL theory being the facilitation of development programmes among 
rural populations, it became necessary to test the workability and practical benefits of the new theory among the people whose emancipation it was designed to promote.

The report that follows is the result of the testing of the Human Development Index Literacy theory in two rural communities of Botswana, Southern Africa.

\section{The Context}

The four major theories of development (classical economic, neo-classical economic, index of sustainable economic welfare and human development index theories) by which the development of the world has so far been explained, all imply that literacy is one of the prerequisites for socio-economic development (Green and Riddell, 2001; Hollander, 1987).

However, the nature of the literacy that is referred to, has never come out clear and unambiguous. For example, schooling, casual traditional literacy programmes, financial literacy and some amount of skills training have all been promoted within the framework of the afore mentioned development paradigms. Additionally, the target audiences for these various types of literacy have rarely been disaggregated. For example, the conceptualisation, contents and indeed the instruments for these literacy programmes were usually developed in technologically advanced societies and exported throughout the world with neither discretion nor discrimination. Furthermore, as posited by Kuhnen (1987), none of the major theories of development ever made literacy the central criterion for development. Capital formation, resources and technologies tend to be emphasised instead (Hollander, 1987). Yet, not all societies share Western societies' notions of capital and capital formation (Ayitteh, 2008).

As a result of these issues in the area of literacy and development, development projects have encountered grave difficulties on the terrains in many parts of the world. These difficulties were more acute in developing countries. Efforts aimed at addressing these difficulties gave birth to three schools of thought by the close of the $20^{\text {th }}$ century. One of the three schools submits that literacy advances socio-economic development (Coulombe, Tremblay and Marchand, 2004; Green and Riddell, 2001; Fagan, 1997). Another of these schools cautions against any categorical statement linking literacy to social and economic development as there are yet to be recorded irrefutable evidences to that effect (Hinzen, 1994; Hinzen, Horn, Leumer and Niemann, 1983). A third school of thought posits that positive correlation between literacy and development is underpinned by more than one factor; according to this school, the success of development projects may be guaranteed only where, on the one hand, the factors underpinning positive correlation between literacy and development are identified prior to literacy planning and on the second hand, the identified factors get imbedded in the implementation process of development projects (see Omolewa, 1998). Unfortunately, this school did not indicate what these factors underpinning positive correlation between literacy and development may be. A fourth school that came on stream in the $21^{\text {st }}$ century, proposes that four areas of knowledge (traditional literacy, basic human science, aesthetics and lifelong learning) need to make up a literacy education programme developed for the purpose of promoting social and economic development in rural Africa (Biao, 2011).

Therefore, at the time of this research, the field of literacy and development remained at a crossroads, not knowing the conclusion to draw after more than seventy years of hard work.

\section{Problem Statement}

After almost a century of research, literacy scholars and development workers held only a wishful thinking that literacy may bring about social and economic development.

For example, between 1995 and 2009, forty-six of the 54 African countries (including South Sudan), were said to have posted between 40 and 88\% literacy rates (UNDP, 2009; Helpme, 2011). Yet, during the same period, the level of development as measured by citizens' access to basic education, lifelong learning and citizens' life expectancy and standard of living in those countries remained abysmally low (United Nations, 2013).

For example throughout the first decade of the $21^{\text {st }}$ century and by the close of that decade, only 1 out of 4 school age youths is in school in Sub-Saharan Africa (United Nations, 2013). Low non-formal education budgets across the continent during the same period (less than 1\% of education budget) (Archer, 2010; Torres, 2003) suggests that hardly has an alternative route to basic education been planned for the teeming out-of-school children and youths. Life expectancy in Sub-Saharan African countries between 2005 and 2010 was pegged between 39 and 63 years (United Nations, 2010). Standard of living is low across the continent. Apart from the fact that between 30 and $39 \%$ of African populations live below national poverty lines, the reduction of rates of poverty, hunger, child and maternal 
mortality and the curtailing of the spread of HIV/AIDS remain the main priorities of most inhabitants of Africa (GiveWell, 2014; United Nations, 2013)

Yet, the literature is replete with the suggestion (we dare say with the belief) that a minimum of $40 \%$ national literacy rate would launch a society or country unto the path of socio-economic development (Bhargava, 2008; Coulombe, Tremblay and Marchand, 2004; Fagan, 1997). As it has been shown here, despite the high literacy rates posted by African countries, the Human Development Indices (as measured by access to and acquisition of basic education, access to lifelong learning opportunities, life expectancy and standard of living) prevailing in those countries remained low and therefore were not consistent with the submission that correlates high literacy rate with impressive socio-economic development.

This observation leads to a number of pertinent questions: What is development? Is development relative to an understanding of a people? Which type of literacy may be used as instrument to drive the development conceived by a people?

\section{Assumptions}

The assumptions that guided the development of the Human Development Index Literacy theory and which underpinned the testing of this same theory through this research were that:

i). The concept of development was relative to the understanding of a people within a space-time continuum.

ii). Participatory approach to development processes would lead to successful implementation of development projects among rural people in Africa.

iii). The typology of literacy that should serve as tool for driving the developmental process need necessarily include the indigenous knowledges relevant to a people concerned and the other aspects of this literacy need to be contributed to by the people whom development is meant for.

iv). Rural people led through development in this manner, will not crave for capital formation as they will be content with whatever they are able to generate within the borders of their communities.

Flowing from the problem statement and the assumptions underpinning both the development of the HDIL theory and its testing is the following research question.

\section{Research Question}

Would the testing of the Human Development Index Literacy Theory over a period of one calendar year lead to the acquisition of increased relevant learning and prospects of longevity and high standard of living?

In other words, after taking a rural people through one year of traditional literacy education in Setswana, basic human science (health, nutrition, safe child bearing), aesthetic (discussion of indigenous knowledges and elimination of harmful cultural practices) and after discussing the concept of lifelong learning, using the Setswana language, would a rural people of Africa

i). Self report a quantitative gain in information and knowledge?

ii). Self report a qualitative gain in information and knowledge?

iii). Self report a prospect of longevity better than the prospect held prior to the HDI literacy training?

iv). Self report a prospect of a standard of living higher than the one held prior to the HDI literacy training?

v). Exhibit any craving for capital formation?

\section{Research Hypotheses}

i). Information acquired during a one calendar year testing of the Human Development Index Literacy theory will bring about a significant shift in perception towards development issues among participants in rural Botswana.

ii). Post treatment scores of Tsetseng and Kacgae communities will be different 


\section{Review of the Literature}

Relevant to the testing of the Human Development Index Literacy theory are a few concepts. These concepts include 'development', 'participatory development', 'theories of development', 'literacy', 'perception' and 'attitude change'.

\subsection{Development}

Although there exists a mosaic of development models, these models can be grouped under two headings, namely the modernisation model of development and the dependency-independence model of development. The modernisation model of development seeks to lead interested persons or groups towards adjusting their thought processes in a way as to favour not only the adoption of modern styles of thinking but also to acquire and ultimately surround themselves with modern environments within which can be found modern objects. As Kuhnen (1987:12) suggests, "a change of the endogenous factors of illiteracy, traditional agrarian structure, the traditional attitude of the population, the low division of labour, the lack of communication and infrastructure" ultimately brings about modernisation.

Historically, the origin of the dependency model of development is traced to the one-sided relationship constructed between Europe and Africa and developing countries. It is a model of development that suggests that the development or "intentional downward development" (Arku and Arku, 2011: 29) of a society is determined by the degree of reliance or dependence that society places on another society. In the words of Arku and Arku (2011:29) "the notion of dependency is that underdevelopment resulted from the same world historical process by which advanced capitalist countries became developed. Thus, the development of Europe was based on external destructions: brutal conquest, colonial control and the stripping of non-Western societies of their resources and surpluses". It is the willingness and ability of a community or society to analyse, assess and own those internal factors that may be worked upon for the purpose of lifting it away from dependency that ultimately leads to socio-economic development.

\subsection{Participatory Approaches to Development}

The terminology "participatory approach" connotes a notion of collaboration. This whole precept is in fact related to the circumstances that gave birth to the development of participatory methods, tools and approaches in development. For a long time in human history and up until the 1970s, development patterns and models were decided in high places and offices and same were rammed down the throat of large populations across the world. However, through a combination of research and flow of rapid world events, a more collaborative and democratic approach to development was developed in the 1970s.

The history of participatory methods in development co-operation began in the late 1970s with the introduction of a new research approach called "Rapid Rural Appraisal (RRA)", which immediately became popular with decision-makers in development agencies. Building on close collaboration with local populations RRAs were designed to collect first-hand data from the local people about their perceptions of their local environments and living conditions in rural areas. RRAs were usually conducted as 1-3 days workshops with villagers in the field and facilitated by small teams of RRA specialists or researchers (Food and Agriculture Organisation (FAO), 2006).

One other reason that was to accelerate the acceptance of participatory approaches to development was the declaration of the World Conference on Agrarian Reform and Rural Development that held in Rome in 1979.

An important milestone in people's participation in rural development was the World Conference on Agrarian Reform and Rural Development (WCARRD - Rome, 1979), which declared participation by rural people in the institutions that govern their lives 'a basic human right' (Guimaraes, 2009).

Therefore, in the world of development work, the notion of participatory development is an acceptable and useful dictum. However, challenges still exist in the areas of application of these approaches in communities. Such challenges relate to application of the approaches to level of researchers' knowledge of the communities within which they work, level of refinement of selected approaches and the mastery with which researchers are able to apply the approaches.

\subsection{Theories of Development}

Four main theories have been used to explain the developmental trends registered by humanity in modern times. They include the classical economic theory, the neo-classical economic theory, the Index of Sustainable Economic Welfare and the Human Development Index theories.

\subsubsection{The Classical Economic Theory}

Although there exists in literature, an economic practice referred to as pre-Adamite Economics-mercantilism-(Blaug, 
1978), in modern times, the classical economic theory is the first main economic theory that commanded wide and wild attention of the international community and it held sway for about 300yrs.

The classical economic theory emphasizes money and money can be said to be its core theme. It promotes the making of money through the setting of wages, interests and rates for all kinds of rental services. The operationalisation of the classical economic paradigm is facilitated through the neat break-up of society into "labourers", "landlords" and capital holders or "capitalists" (Hollander, 1987).

\subsubsection{The Neo-classical Economic Theory}

Where classical economic theory emphasises land, capital and labour, neo-classical economic theory highlights resources (some capital, relevant materials and/or mineral resources), technology (machines and knowledge to operate them) and preferences (deliberate choice of the types of products individuals or societies wish to have) (Hoff and Stiglitz, 2010).

Both classical and neo-classical economic theorists, although slightly different, emphasise income, revenue and capital as indispensable ingredients for social development.

\subsubsection{The Index of Sustainable Economic Welfare Theory}

The Index of Sustainable Economic Welfare (ISEW) theory is one of the two human-centred development theories because in addition to capital formation and acquisition of financial resources, it emphasises the cost of the degradation of the natural environment to human welfare (Hamilton, 1999; Jackson, 2011).

The following is the formula used to derive the ISEW equation.

\section{ISEW=Personal consumption + public non-defensive expenditures + capital formation + services from domestic labour (costs of environmental degradation, depreciation of natural capital).}

\subsubsection{The Human Development Index Theory}

The Human Development Index was designed to measure life expectancy, literacy, education and standard of living (UNDP, 2013). In other words, if any society made appreciable progress on these indicators, it will be seen as having attained some level of social development. The United Nations currently categorises nations as either very high, high, medium or low using the Human Development Index indicators.

However, while this much progress has been registered in the effort at devising an equitable formula of development for the world, there seems to be more room for improvement.

\subsection{Beyond Human-centred Theories of Development}

The propositions and methodologies of human-centred social development theories (Index of Sustainable Economic Welfare (ISEW) and Human Development Index (HDI) are that capital formation, capital and indeed technologies are pre-requisites for the actualisation of human-centred social development. In other words, the first step towards the actualisation of a human-centred social development programme is for the state or corporate entity to first accumulate capital and technologies with the view to using same for the provision of health schemes, nutritional regimes, educational systems that will eventually permit citizens to access longevity, quantitative and/or qualitative education, sustainable environment and high or acceptable standard of living.

Yet, not all societies may have access to the amount of capital that may help promote longevity, modern education and high standard of living to the level advocated by current human-centred development theories.

Consequently, if all socio-economic development projects in developing countries were to be tied to availability of capital, no matter how humane or humanitarian, they are bound to encounter difficulties.

Is it surprising therefore that in spite of the efforts deployed by the international community with the view to bringing social development to as many societies as possible in the course of preceding centuries, many societies still remain under-developed?

\subsection{Literacy and Literacy Education}

Literacy is both a tool and a concept. As tool, it has been used by humankind to facilitate interpersonal interaction for millennia; as concept, it emerged with advancement in both human consciousness and civilisation whereby at a stage in human history, yardsticks and criteria began to be fixed, albeit inaccurately, to profile a literate person.

First, language symbols were invented that needed to be used fairly accurately (Gascoigne, 2001). Second, various numbers of common words were prescribed that needed to be mastered in daily use (Hladczuk, Eller and Hladczuk, 1990; Okedara, 1981). Third, competencies were listed that were to be demonstrated (Laubach and Mujahid, 1971 in 
Okedara,1981). Fourth, by the close of the $20^{\text {th }}$ century, myriad definitions of literacy appeared in literature which came to render literacy and literacy education activities more complex (Lindmark, Erixon and Simon, 2008; Beers and Orzech, 1996)

\subsection{Psychological Implications of Social Change}

The process and outcome of social development and social change are all a function of the manner the world is both viewed and accepted. The establishment of a world view itself is usually born out of a process which begins with the way the world or environment is perceived and ends with credible knowledge with which old attitudes are changed and new ones are adopted. "Perception" and "attitude" are two psychological constructs relevant to the present discussion.

\subsubsection{Perception}

Perception is the process of reaching understanding of the environment in which one lives through the analysis and organisation of information gathered in a sensory, mental and/or psychic manner. The hypothesis testing perception theory (Hohwy, 2012; Gibson, 2002), action oriented perception theory (Hurtley, 2002; Anderson, Reder and Simon, 1998) and evolutionary perception theory (Gaulin and McBurney, 2003) are three main theories that explain the manner in which

i). Human beings reach understanding of their environment through the analysis of the many pieces of information that are received by them,

ii). The analysis of the pieces of information forms the basis of action that human beings take subsequently and

iii). The processes of analyses and actions gradually help to enlarge the world view of the individual.

\subsubsection{Attitude and Attitudinal Change}

Attitudes are observable or non-observable dispositions and behaviours whose origin usually derives from specific previous experiences and/or beliefs. Cognitive dissonance theory (Cooper and Fazio, 1984), emotion based attitude change theory (Breckler and Wiggins, 1992; Bandura, 1982) and expectancy-value theory (Cialdini and Goldstein, 2004) are three theories of attitude that indicate the manner in which

i). Individuals reconcile conflicting previously accepted knowledges to bring internal equilibrium

ii). Emotion may override cognition under specific circumstances and

iii). The process of human development equips the individual with a value system and how all subsequent acceptance or rejection of views are done against the background of this internal value system.

\subsection{The Human Development Index Literacy Theory}

The Human Development Index Literacy (HDIL) theory was developed in 2011(Biao, 2011). The theory was evolved as a result of the failure of past literacy efforts to yield a convincing correlation between literacy and development. The development of HDIL theory was based on the premises that:

i). Development in the $21^{\text {st }}$ century will become increasingly knowledge based

ii). The minimal level of knowledge-bringing education available is basic literacy

iii). With little or no capital, basic literacy may be promoted and rolled out

iv). None of the four major theories of development since Adam Smith's An inquiry into the nature and causes of the wealth of nations (1776), made literacy a pivotal concept and instrument for socio-economic development.

The HDIL theory of socio-economic development displays four main features. First, it is founded on the most basic of all education (literacy education). Second, to this literacy education is imputed specific socio-economic development criteria. Third, the implementation process of this literacy education includes the exploration and adoption of relevant indigenous knowledges and fourth, it is a literacy that promotes acquisition of knowledges from the public domain through the promotion of lifelong learning (for details, see Biao, 2011).

\section{Methodology}

\subsection{The Design of the Testing}

The process of testing the Human Development Index Literacy theory was a quasi experimental activity. Five days after initial Focus Group Discussions that explained the purpose of the research, self-reports were collected in two 
communities (Tsetseng and Kacgae) of Botswana relating to the five aspects of the research question. Then an eight-month (July 2013-February 2014) literacy education programme was implemented among 80 participants (40 from each community) in the two communities. At the end of the eight-month literacy education programme, self-report evaluations were collected relating to the five aspects of the research question.

A 5-scale instrument (Very low, Low, Normal, High, Very high, numbered 1-5) was designed to capture and interpret the rates of achievement reported within each of the areas tested.

\subsection{The Research Area}

The testing took place in two communities of Botswana. Botswana is a Southern African country that attained independence on 30 September, 1966. It has enjoyed high international ratings on account of good governance and a high Gross Domestic Product per capita. Botswana's more than \$12,000 GDP per capita (UNDP, 2013) did not drop significantly during the 2007-2011 world economic recession and the shock of the recession to public spending was equally minimal (World Bank, 2011).

The two communities, Tsetseng and Kacgae lie in the Kalahari Desert about 500kms to Gaborone, Botswana Capital City. They are each inhabited by about 400 people (Republic of Botswana, 2011). Tsetseng and Kacgae are rural communities whose livelihood activities revolve around farming, hunting and craft works.

\section{Ethical Considerations}

Ethics is about informed consent, permission and confidentiality. Ethics is equally about knowing traditional community unwritten codes and protocols that permit entrance into the domains of potential participants to a project or programme. Not only was the purpose of this research explained to community members before hand, their consent to participate was sought and obtained. Community members were also assured of confidentiality and safe keeping of names and research results and the communities were entered using appropriate linguistic and cultural icons.

\section{Findings}

Table 1. General Information on Participants

\begin{tabular}{|c|c|c|c|c|c|c|c|c|}
\hline \multirow[t]{2}{*}{ Communities } & \multirow[t]{2}{*}{ Male } & \multirow[t]{2}{*}{ Female } & \multirow[t]{2}{*}{ Total } & \multicolumn{3}{|l|}{ Age } & \multicolumn{2}{|c|}{ Education level } \\
\hline & & & & Youngest & Oldest & $\begin{array}{l}\text { Mean } \\
\text { bracket }\end{array}$ & $\begin{array}{l}\text { Elemen } \\
\text { tary }\end{array}$ & $\begin{array}{l}\text { No } \\
\text { schooling }\end{array}$ \\
\hline Tsetseng & $5(13 \%)$ & $35(87 \%)$ & 40 & $\begin{array}{l}39 y r s-2 \text { participants } \\
(5 \%)\end{array}$ & $\begin{array}{l}\text { 61yrs-3part. } \\
(7 \%)\end{array}$ & $\begin{array}{l}51-57 \mathrm{yrs}-35( \\
88 \%)\end{array}$ & $\begin{array}{l}4 \text { parti. } \\
(10 \%)\end{array}$ & $\begin{array}{l}\text { 36part } \\
(90 \%)\end{array}$ \\
\hline Kacgae & $6(15 \%)$ & $34(85 \%)$ & 40 & $\begin{array}{l}\text { 38yrs-4participants } \\
(10 \%)\end{array}$ & $\begin{array}{l}60 \mathrm{yrs}-2 \text { part. } \\
(5 \%)\end{array}$ & $\begin{array}{l}49-56 y r s-34( \\
85 \%)\end{array}$ & $\begin{array}{l}5 \text { partic } \\
(12 \%)\end{array}$ & $\begin{array}{l}\text { 35parti } \\
(88 \%)\end{array}$ \\
\hline Total & $\begin{array}{l}11 \\
\text { participants } \\
(14 \%)\end{array}$ & $\begin{array}{l}69 \\
\text { participants } \\
(86 \%)\end{array}$ & $\begin{array}{l}80 \text { partici } \\
(100 \%)\end{array}$ & 6participants (8\%) & 5 parti $(6 \%)$ & 69pari (86\%) & $\begin{array}{l}9 \text { partic } \\
(11 \%)\end{array}$ & $\begin{array}{l}\text { 71parti } \\
(89 \%)\end{array}$ \\
\hline
\end{tabular}

Table 1 shows that more than three quarters of the participants $(86 \%)$ to the testing of the Human Development Index Literacy theory were female. In Tsetseng $87 \%$ of the participants were female while in Kacgae, $85 \%$ of them were female. Only $14 \%$ of the participants were male.

Taken together, $86 \%$ of the participants were aged between 49 and 57 years with Kacgae participants being slightly younger. The youngest participants were aged between 38 and 39 years and they made up $8 \%$ of the total participants while the oldest participants were aged between 60 and 61 years and they constituted $6 \%$ of all the participants.

Eighty-nine percent of all the participants never attended any formal school while $11 \%$ of the participants had the opportunity of attending elementary school without necessarily completing the educational cycle. 
Table 2. Summary of Findings

\begin{tabular}{|c|c|c|c|c|}
\hline \multirow[t]{2}{*}{ Literacies Tested } & \multirow{2}{*}{$\begin{array}{c}\text { Time } \\
\text { BEFORE } \\
\text { IMPLEMENTATION } \\
\text { Tsetseng }\end{array}$} & \multirow{2}{*}{$\begin{array}{c}\text { OF } \\
\text { HDIL } \\
\text { Kacgae }\end{array}$} & \multicolumn{2}{|c|}{$\begin{array}{c}\text { Frame } \\
\text { AFTER IMPLEMENTATION OF } \\
\text { HDIL }\end{array}$} \\
\hline & & & Tsetseng & Kacgae \\
\hline $\begin{array}{l}\text { Traditional literacy in } \\
\text { Setswana }\end{array}$ & 2 & 2 & 3 & 4 \\
\hline $\begin{array}{l}\text { Traditional literacy in } \\
\text { English }\end{array}$ & 1 & 2 & 1 & 3 \\
\hline Basic Human Science & 2 & 3 & 3 & 3 \\
\hline Indigenous Knowledges & 4 & 4 & 5 & 5 \\
\hline $\begin{array}{l}\text { Harmful Cultural } \\
\text { Practices }\end{array}$ & 2 & 2 & 2 & 3 \\
\hline $\begin{array}{l}\text { Concept of Lifelong } \\
\text { Learning }\end{array}$ & 1 & 1 & 1 & 1 \\
\hline $\begin{array}{l}\text { Craving for Capital } \\
\text { Formation }\end{array}$ & 4 & 5 & 4 & 5 \\
\hline
\end{tabular}

Table 2 shows that after the implementation of the Human Development Index Literacy in Tsetseng, moderate improvement was recorded in three areas, namely in Setswana, Basic Human Science and Indigenous knowledge literacies. No change in achievement was recorded in four areas, namely in English, Harmful cultural practices, Lifelong learning and Capital formation. Table 2 also shows that after implementation of the Human Development Index Literacy in Kacgae, some improvement was recorded in four areas, namely in Setswana, English language, Basic Human Science and Indigenous Knoledge literacies. No change in achievement was recorded in three areas, namely, in Harmful cultural practices, Lifelong learning and Capital formation.

Table 3. The Difference between Participants Post and Pre HDIL Treatment Scores in Tsetseng Will not be Significant

\begin{tabular}{lllll}
\hline $\operatorname{Diff}(\mathrm{T} 2-\mathrm{T} 1)$ & Sq. Dev & df & $\mathrm{t}$ & $\mathrm{p}$ \\
\hline 0.43 & 1.71 & .29 & 2.12 & 0.03907 \\
\hline \multicolumn{5}{c}{$\mathbf{P} \leq \mathbf{. 0 5}=$ significant }
\end{tabular}

Table 3 shows that the post-treatment score of participants was significantly higher than their pre-treatment score in Tsetseng as $\mathrm{P} \leq .05$.

Table 4. The Difference between Participants Post and Pre HDIL Treatment Scores in Kacgae Will not be Significant

\begin{tabular}{lllll}
\hline $\operatorname{Diff}(\mathrm{T} 2-\mathrm{T} 1)$ & Sq. Dev & $\mathrm{df}$ & $\mathrm{t}$ & $\mathrm{p}$ \\
\hline 0.71 & 3.43 & .57 & 2.50 & 0.023264 \\
\hline \multicolumn{5}{c}{$\mathbf{P} \mathbf{. 0 5}=$ significant }
\end{tabular}

Table 4 shows that participants' total post-treatment score was significantly higher than their total pre-treatment score in Kacgae as $\mathrm{P} \leq .05$.

Table 5. The Difference between Participants Post HDIL Treatment Scores in Tsetseng and Kacgae Will not be Significant

\begin{tabular}{lllll}
\hline Diff (T2.T-T2.K) & Sq. Dev & df & t & P \\
\hline 0.71 & 3.43 & .57 & 2.50 & 0.046528 \\
\hline \multicolumn{5}{c}{$\mathbf{P} \leq \mathbf{. 0 5}=$ significant }
\end{tabular}

Table 5 shows that the post-treatment score in Kacgae was significantly higher than the post-treatment score in Tsetseng as $\mathrm{P} \leq .05$. 


\section{Discussion of Findings}

Although they scored low (2/5) on the inventory employed to interpret their reports in the area of harmful cultural practices during the pre-HDIL testing, the two communities did not show an improvement in this literacy area during the HDIL activities. When asked for clarification and for possible reasons that may account for this lack of improvement, participants pointed to the fact that a number of their cultural practices which were previously labeled unacceptable and barbaric are currently being brought back by government and 'white people' as helpful to healthy living. They cited male circumcision and "living surrounded by bush" as two such practices.

In much of Southern Africa, male circumcision is currently being promoted by governments as a means for reducing the rate of HIV infection. Additionally, a few Southern African governments are currently relocating whole ethnic groups from woody areas with the view to settling them on grass land surrounded by modern amenities. On arriving on their designated grassland, these ethnic groups get encouraged and even assisted by governments in planting trees within and around their new environments. This practice was viewed by the indigenous communities as being contradictory as there were a lot of wild trees in the places from where they were moved.

The last assumption of this study which states that rural participants will not crave for capital formation after going through the HDIL treatment was rejected by the self-reports of participants. All participants in the two communities scored "high" (4/5 in Tsetseng) and "very high" (5/5 in Kacgae) in their craving for financial wealth. Upon further discussion, the participants submitted that the only way they may live a fairly decent life is to be helped to commercialise their indigenous knowledges in a "Botswana where that which counts is Pula (or money in reference to the Botswana currency)". This perception of the participants is consistent with the submission that colonisation and globalisation have come to alter the framework within which a number of African practices had had value (Biao, Esaete and Oonyu, 2013). One example of this alteration is the extent to which the concept and importance of money has become pervasive throughout the fabrics and consciousnesses of even the inhabitants of remote parts of Africa and the developing world.

One other unexpected information thrown up by this study is the deep seated neglect of the concept of lifelong education among the participants. When participants were requested to indicate those pieces of knowledge they would like to have packaged for them over the next 5 and 10 years, their response was "Are we still going to be around?" "How long more are we going to live?" In other words, the participants were not ready to commit themselves to any long plan for learning as they feel that they are too advanced in age to get involved in such an educational plan. Yet, the oldest of the participants as could be seen from table 1 is 61years. Some of the participants are as young as 48 years, yet, they too were neither keen on getting involved into discussion about lifelong learning nor actually plan for a type of lifelong learning.

Consequently, while the HDIL treatment may have significantly impacted participants in the areas of Setswana, English (the teaching of English language was specially requested for by the Kacgae participants), basic human science and indigenous knowledges, it has failed to encourage them to embrace modern lifelong learning.

\section{Conclusion}

The testing of the HDIL has thrown up interesting pieces of information that should enable policy makers to better appreciate the perception of rural dwellers in Botswana and Africa. For example, It came out clearly that rural dwellers may lack literacy skills in a few knowledge areas, they are neither ignorant nor do they go without reflecting over the actions of government and all they come across. They are observant and they are able to pinpoint the areas where governments, and persons portrayed as being superior to them have blundered. These observational and reflective abilities eventually tend to sharpen and reshape their perceptions which in turn help them to adopt attitudes and behavioural patterns consistent with their own world views.

One obvious consequence of the reflective abilities of these rural populations is their decision to seek for capital formation since the world around them is moving towards this direction and since not to follow suit may negatively impact the quality of their life in the long run.

The main finding of the study was that HDIL has proved to possess the potential of promoting socio-economic development among rural populations in Botswana as post training perception scores of participants were found to be significantly higher than perception scores recorded before training on the Human Development Index Literacy. Recommendations need therefore to be made going forward with this theory. 


\section{Policy Recommendations}

Even in Botswana where according to participants financial wealth is important, the Human Development Index Literacy theory has made some positive impact. In order therefore to reduce the risks of failure at the level of future socio-economic development projects in developing countries,

Governments, in conjunction with development partners, should encourage the awakening of interest in indigenous knowledges and

Should build all future development projects designed for the developing world on the Human Development Index Literacy theory.

\section{References}

Anderson JR. Reder LM., \& Simon HA. (1998). Radical constructivism and cognitive psychology. London: Routledge Falmer. Retrieved from http://memory.psy.cmu.edu/publications/98_jra_lmr_has.pdf

Archer D. (2010). CONFINTEA in the Context of the Financial Crisis: Challenges and Opportunities. IIZ/DVV, 75, 71-74.

Arku C., \& Arku FS. (2011). Development constructs and gender relations: Assessing rural gender relations within the context of dependency theory and globalization. Journal of Peace, Gender and Development Studies, 2, 28-33.

Ayittey G. (2008). Concepts of wealth in traditional Africa. USA: Ayittey.org. Retrieved from http://cuwhist.files.wordpress.com/2010/04/concepts-of-wealth-in-traditional-africa.docx

Bandura A. (1982). Self-efficacy mechanism in human agency. American Psychologist, 37, 122-147. http://doi.org/10.1037/0003-066X.37.2.122

Beers MI, \& Orzech MJ. (1996). World Wide Web literacy. Proceedings of the Site 99 conference. NY: USA. http://www.clab.edc.uoc.gr/hy302/texts/SITE99.PDF

Bhargava A. (2008). Globalization, literacy levels and economic development. Helsinki: United Nations University. Retrieved from http://wider.unu.edu/publications/working-papers/research-papers/2008/en_GB/rp2008-04/

Biao I, Esaete J, \& Oonyu J. (2013). The role of building learning cities in the rejuvenation of Africa. International Review of Education, 59(4), 469-488. http://doi.org/10.1007/s11159-013-9368-y

Biao I. (2011). Human Development Index Literacy as a new Social Development Theory. International Critical Thought, 1(4), 385-396

Blaug M. (1966). Literacy and economic development. Paris: UNESCO. Retrieved from http://eric.ed.gov/?id=ED016174

Breckler SJ, \& Wiggins EC. (1992). On defining attitude and attitude theory: Once more with feeling. In Pratkanis, A.R., Breckler, S. J. \& Greenwald, A. G. (eds.). Attitude structure and function. Hillsdale, NJ: Erlbaum.

Cialdini RB, \& Goldstein NJ. (2004). Social influence: compliance and conformity. Annual Review Psychology, 55, 591-621. http://doi.org/10.1146/annurev.psych.55.090902.142015

Cooper J., \& Fazio RH. (1984). A new look at dissonance theory. Advanced Experimental Social Psychology, 17, 229-266.

Coulombe S., Tremblay J., \& Marchand S. (2004). Literacy scores, human capital and growth across fourteen OECD countries. Canada: Government of Canada. Retrieved from http://www5.statcan.gc.ca/olc-cel/olc.action?ObjId=89-552-M2004011\&ObjType=46\&lang=en\&limit=0

Crawford C., \& Krebs D. (2008). Foundations of evolutionary psychology. New York: Taylor \& Francis Group. Retrieved

from http://books.google.co.bw/books?id=19eFste7qkcC\&pg=PT132\&lpg=PT132\&dq=Gaulin+SJ,++McBurney+DH .+\%282003\%29.+Evolutionary+psychology.\&source=bl\&ots=ayupXbGRSr\&sig=TkhvCcW

Fagan WT. (1997). Adult basic education(ABE) and literacy: Newfoundland and Labrador. Newfoundland: Memorial University. Retrieved from http://www.mun.ca/educ/faculty/mwatch/fall97/abe.htm

Food and Agriculture Organisation. (2006). Module II: Introducing participatory approaches, modules and tools. New York: Economic and Social Development Department. Retrieved from 
http://www.fao.org/docrep/006/ad424e/ad424e03.htm

Gascoigne B. (2001). History of writing. UK: History World. Retrieved from http://www.historyworld.net/wrldhis/PlainTextHistories.asp?historyid=ab33

Gibson JJ. (2002). A theory of direct visual perception. Noc A, Thompson E. editors Vision and mind: Selected Readings in the Philosophy of perception. Cambridge: MIT Press. Retrieved from $\mathrm{http} / / /$ ebookbrowsee.net/alva-noc3ab-and-evan-thompson-vision-and-mind-pdf-d475864776

GiveWell. (2014). Standard of living in the developing world. San Francisco: Clear Fund. Retrieved from http://www.givewell.org/international/technical/additional/Standard-of-Living

Green DA, \& Riddell CW. (2001). Literacy, Numeracy and Labour Market Outcomes in Canada. Canada: Government of Canada; 2001 March 19. Retrieved from http://www5.statcan.gc.ca/olc-cel/olc.action?ObjId=89-552-M2001008\&ObjType=46\&lang=en\&limit=0

Guimaraes C. (2009). Participatory approaches to rural development and rural poverty alleviation. The Hague: ESCAP. Retrieved from http://sergiorosendo.pbworks.com/f/Guimaraes+2010+participatory_rural.pdf

Hamilton C. (1999). The genuine progress indicator: Methodological developments and results from Australia. Ecological Economics, 30, 13-28. http://dx.doi.org/10.1016/so921-8009(98)00099-8

Hautecoeur J. (1997). Literacy on the eve of CONFINTEA: Observations, Questions and Action plans. IIZ/DVV, 49, 63-77.

Helpme. (2011). Adult illiteracy rate in various countries and grouped populations. USA: Helpme. Retrieved from $\mathrm{http}: / /$ www.123helpme.com/view.asp?id=120601

Hinzen H., Horn J., Leumer W., \& Niemann R. (1983). Cooperation or campaigning for literacy: Let's remove doubtful promises and cope with the practicable. IIZ/DVV, 21, 30-42.

Hinzen H. (1994). Policy and practice of literacy: Experiences and interpretations. IIZ/DVV, 43, 213-245.

Hladczuk J, Eller W, \& Hladczuk S. (1990). General issues in literacy/illiteracy. New York: Greenwood Press.

Hoff K., \& Stiglitz J. (2010). Modern economic theory and development. New York: World Bank. Retrieved from http://siteresources.worldbank.org/DEC/hoff-stiglitz-frontiersofdevec.pdf

Hohwy J. (2012). Attention and consciousness perception in the hypothesis testing brain. Lausanne, Switzerland: Frontiers, 3, 86-96. Retrieved from http://journal.frontiersin.org/Journal/10.3389/fpsyg.2012.00096/abstract

Hollander S. (1987). Classical economics. Oxford: Blackwell.

Hurley SL. (2002). Consciousness in action. Havard: Havard University Press. Retrieved from http://www.hup.harvard.edu/catalog.php?isbn=9780674007963

Jackson T. (2011). Confronting consumption: challenges for economics and for policy. In Dietz S, Michie J, \& Oughton C. (eds.). The Political Economy of the Environment: an Interdisciplinary approach. (New York): Routledge.

Kuhnen F. (1987). Causes of underdevelopment and concepts for development -An introduction to development theories. Peshawar: University of Peshawar. Retrieved from http://www2.fiu.edu/ ereserve/010029280-1.pdf

Lindmark D., Erixon P., \& Simon, F. (2008). Technologies of the word: Literacies in the History of Education. International Journal of the History of Education, XLIV(I \& II), 1-198.

Okedara, J. T. (1981). Concepts and measurements of literacy, semiliteracy and illiteracy. Ibadan: Ibadan University Press.

Omolewa M. (1988). On the Intractable Question of Literacy Campaigns in Nigeria. DVV, 31, 45-51.

Omolewa, M. (1998). Literacy, income generation and poverty alleviation. In Omolewa M, Osuji E, \& Oduaran A. (eds.). Retrospect and Renewal: The State of Adult Education Research in Africa. Dakar: UNESCO Regional Office in Africa; 1998.

Republic of Botswana. (2011). Household census. Gaborone: Government Press.

Smith A. (1776). An inquiry into the nature and causes of the wealth of nations. Liberty Fund Inc. Retrieved from http://www.econlib.org/library/Smith/smWN0.html

Torres MR. (2003). Lifelong learning: A new momentum for ABLE. IIZ/DVV, 60, 1-254 
UNDP. (2009). List of countries by literacy rate. Pakistan: Civil Service of Pakistan. Retrieved from http://www.cssforum.com.pk/off-topic-section/general-knowledge-quizzes-iq-tests/36626-list-countries-their-lit eracy-rate-undp-2009-report.html

UNDP. (2013). Human Development Index. New York: UNDP. 2013. Retrieved from http://hdr.undp.org/en/statistics/hdi

UNESCO. (1995). History of Unesco. Paris: UNESCO; 2010. Retrieved from http://www.unesco.org/archives.news2010/en/history

United Nations. (2010). World Population Prospects Report, 2005-2010. New York: UN. Retrieved from http://www.un.org/esa/population/publications/wpp2006/English.pdf

United Nations. (2013). The Millennium Development Goals Report 2013. New York: UN. Retrieved from http://www.un.org/millenniumgoals/pdf/report-2013/mdg-report-2013-english.pdf

World Bank. (2011). World development indicators data base. New York: World Bank. Retrieved from: http://data.worldbank.org/WDI-2011 